\title{
Hexavalent chromium exposure alters bone remodeling in the developing tooth alveolus and delays tooth eruption
}

\author{
Luciana M. Sánchez, Ángela M. Ubios \\ Universidad de Buenos Aires, Facultad de Odontología, Cátedra de Histología y Embriología, Buenos Aires, Argentina
}

\begin{abstract}
Although it has been demonstrated that exposure of lactating rats to CrVI delays tooth eruption, the effects of CrVI exposure on bone remodeling in the developing alveolus during tooth eruption remain unknown. Our purpose was to analyze the effect of CrVI in the alveolus of the first lower molar of rats. Thirty-two suckling Wistar rats were divided into two groups. The experimental group received $12.5 \mathrm{mg} / \mathrm{kg}$ body weight/day of potassium dichromate dissolved in saline solution by oral gavage as of day 4 of the experiment; the control group received an equal dose of saline solution. Each group was divided into two sub-sets and euthanized at the ages of 9 and 15 days, respectively. Histochemical and histomorphometric studies of the bone surfaces of the developing tooth alveolus were
\end{abstract}

performed. The percentage of bone formation surfaces was lower in experimental animals than in age-matched controls. The percentage of bone resorption surfaces was significantly lower in 9-day-old experimental rats than in controls and significantly higher in 15-day-old experimental rats than in controls. Exposure to CrVI during lactation alters the sequence of bone resorption and formation in the walls of the developing alveolus, both of which are necessary for tooth eruption, thus causing a delay.

Received: March 2021; Accepted: June 2021.

Keywords: CrVI - tooth eruption - bone remodeling - tooth socket - rat.

\section{La exposición a cromo hexavalente altera la remodelación ósea del alvéolo dental en desarrollo y retarda la erupción dentaria}

\begin{abstract}
RESUMEN
Si bien ya ha sido demostrado que la exposición a CrVI de ratas lactantes retrasa la erupción dentaria, aún se desconocen los efectos de la exposición a CrVI que se producen sobre la modelación y remodelación de las paredes del alvéolo en formación que ocurren en los diferentes estadios de la erupción dentaria. Por tal motivo, el propósito de este trabajo fue estudiar el efecto del CrVI sobre la formación y la reabsorción óseas del alvéolo del primer molar inferior en desarrollo en ratas, a los 9 y a los 15 dias de edad, que corresponden a los estadios intraóseo y de penetración mucosa de la erupción dentaria, respectivamente. El grupo experimental recibió una dosis diaria de $12,5 \mathrm{mg} / \mathrm{kg}$ de peso corporal de dicromato de potasio disuelto en solución salina por sonda bucal a partir del $4^{\circ}$ día; mientras que el grupo control, un volumen equivalente de solución salina. Cada grupo fue dividido en 2 subgrupos de acuerdo al tiempo experimental en el que se llevó a cabo la eutanasia: 9 y 15 dias de edad. Se llevaron a cabo estudios histoquímicos e histomorfométricos de las superficies óseas de los alveólos dentarios en formación. Los datos fueron analizados estadísticamente utilizando la prueba t de Student;
\end{abstract}

estableciéndose un valor de $p<0,05$ como estadísticamente significativo. El porcentaje de superficies en formación fue menor en los animales experimentales de 9 y de 15 dias de edad que en los respectivos controles. El porcentaje de superficies en reabsorción en los animales experimentales de 9 días de edad fue significativamente menor y en los animales de 15 dias de edad fue significativamente mayor con respecto a sus controles. La exposición al cromo hexavalente durante la lactancia altera la secuencia de la reabsorción y la formación ósea de las paredes del alvéolo en desarrollo necesarias para que la pieza dentaria erupcione, causando su retraso. Los hallazgos obtenidos muestran la importancia del control de sustancias tóxicas en el agua potable, ya que sus efectos pueden alterar la remodelación ósea y por ende, el crecimiento y el desarrollo de los individuos que fueron expuestos durante la infancia temprana.

Palabras clave: CrVI - erupción dentaria - remodelación ósea - alvéolo dentario - rata. 


\section{INTRODUCTION}

The heavy metal hexavalent chromium (CrVI), which can be found in the soil, air and water in industrial areas in large cities around the world, is very dangerous to human health ${ }^{1-3}$. Hexavalent chromium has been found in inadequately treated wastes from petrochemical and leather industries that are discharged into rivers ${ }^{4}$. Exposure to $\mathrm{CrVI}$ can affect the population at large $\mathrm{e}^{5,6}$ and children in particular ${ }^{7}$. In lactating infants, exposure can occur through breast milk from contaminated mothers ${ }^{8}$ or by ingesting infant formula prepared with contaminated water ${ }^{9,10}$. A child's behavior and life-style also influence exposure. Children crawl on the floor, put things in their mouths, and eat inappropriate things such as dirt or paint chips. It has been reported that materials containing CrVI (plastics, dyes and paints) used to manufacture toys can be another source of exposure ${ }^{11}$.

Dental eruption involves the movement of a tooth from its site of development in the jaw bone to its functional position in the oral cavity. Andreasen et al. ${ }^{12}$ divided this continuous process into five stages: preeruptive movements, intraosseous eruption, mucosal penetration, preocclusal eruption, and postocclusal eruption. Each stage involves interactions between the developing tooth and the surrounding periodontal tissues, and it is temporally and spatially controlled to coordinate the growth of the jaws and the position of other adjacent and antagonist teeth ${ }^{13}$. The most widely accepted theory at present explaining the tooth eruption process under normal physiological conditions involves the action of bone modeling and remodeling ${ }^{14}$. The mechanism of bone modeling involves formation and resorption processes of different and often opposite bone surfaces. Bone formation occurs at the base of the developing alveolus, facilitating tooth eruption, whereas bone resorption occurs at the lateral walls and especially the bone overlying the crown of the tooth ${ }^{15}$. Simultaneously, the developing alveolar bone begins to undergo a remodeling process ${ }^{16}$. Bone remodeling involves the coordinated and coupled action of osteoclasts and osteoblasts at specific sites on the bone surface with the final aim of replacing and renewing the bone matrix ${ }^{17}$. Pathological conditions, as is CrVI exposure, impair the tooth eruption process ${ }^{18,19}$. The effects of CrVI exposure on bone tissue in rats include alterations in bone formation $^{20}$ and resorption ${ }^{21}$, and in bone growth ${ }^{22,23}$.
Moreover, defects in skeletal development in children born in contaminated areas close to leather tanning processing plants have been reported ${ }^{24}$.

Previous studies conducted by our research group have shown that tooth eruption is delayed in suckling rats exposed to hexavalent chromium ${ }^{18,19}$.

Nevertheless, the effects of CrVI exposure on modeling and remodeling of the walls of the developing alveolus at the different stages of tooth eruption remain unknown. Therefore, the aim of the present work was to study the effects of CrVI on bone formation and resorption of the alveolus of the developing first lower molar of 9- and 15-day-old rats, which correspond to rats in the intraosseous and mucosa penetration stages of tooth eruption, respectively.

\section{MATERIALS AND METHODS}

Thirty-two suckling Wistar rats aged 4 days at the onset of the experiment were used. Experimental animals received daily $12.5 \mathrm{mg} / \mathrm{kg}$ of body weight of potassium dichromate (Biopack, Argentina) dissolved in saline solution by oral gavage until the day prior to euthanasia. Both the experimental and control groups were divided into two sub-sets of eight animals each according to age at euthanasia: 9 and 15 days, which correspond to the intraosseous and mucosa penetration stages of tooth eruption, respectively.

All the animals were housed throughout the experiment with their corresponding dam (8 pups/ dam) in individual metal cages $30 \mathrm{~cm}$ high, 40 $\mathrm{cm}$ wide, $40 \mathrm{~cm}$ deep, with wood chip bedding. The animals were kept under controlled housing conditions: 7-hour light/dark cycles, 20 to $26^{\circ} \mathrm{C}$ temperature, and 40 to $70 \%$ humidity. The dams were allowed free access to solid chow pellets and water ad libitum. The pups were returned to their cage with their dam after each procedure.

This study was approved by the Institutional Ethics Committee for the Care and Use of Laboratory Animals of the School of Dentistry of the University of Buenos Aires (Res. No. 27/03/2013-51), and all the experiments were conducted in keeping with The National Institutes of Health Guidelines for the Care and Use of Laboratory Animals (NIH publication 85-123 Rev. 2010).

Immediately after euthanasia, the mandibles were resected and fixed in $4 \%$ formaldehyde in PBS at $4^{\circ} \mathrm{C}$ for 48 hours, decalcified in $10 \%$ EDTA, and 
embedded in paraffin. Buccolingually oriented sections were obtained at the level of the mesial root of the first lower molars under a stereoscopic microscope (Nikon, Japan). Serial sections were stained with routine H\&E and alkaline phosphatase (ALP) and tartrate-resistant acid phosphatase (TRAP) histochemical techniques, used as markers of bone formation and bone resorption, respectively. Photomicrographs of the histologic sections were taken using a light field microscope (Axioskop 2; Carl Zeiss, Jena, Germany) and a digital camera (Nikon CoolPix $12 \mathrm{Mp}$ ). The images were used to perform the histomorphometric analysis of the developing alveolus using Image Pro ${ }^{\circledR}$ Plus software, version 5.1 (Media Cybernetics), following the stereological principles described by Weibel and Elias ${ }^{25}$, and using the nomenclature employed by Parfitt et al. ${ }^{26}$ and revised by Depster et al. ${ }^{27}$.

\section{Histomorphometric Analysis}

Digital images of the TRAP-stained sections were used to assess the resorption activity of the inner wall of the forming socket. During tooth eruption, bone resorption occurs only in the most superficial third. Therefore, TRAP+ edges were measured at a length of $500 \mu \mathrm{m}$ from the point closest to the tip of the crown in both the buccal and lingual directions (See Fig. 1 for orientation), and expressed as percentage. Digital images of ALP-stained sections were used to measure the percentage of ALP+ bone formation in the total bone edge of the developing alveolus.

Data were analyzed statistically using Student's t test, setting statistical significance at $\mathrm{p}<0.05$.

\section{RESULTS}

The histologic features of the first molars in the intraosseous and mucosa penetration stages of both experimental and control animals are shown in Fig. 1.

At age 9 days, the tooth germs of both groups were covered with bone and oral mucosa. The distance between the tooth germs and the surface of the oral mucosa was greater in CrVI-exposed animals, which thus showed a decreased eruption rate. Thickness of developing dental tissues was less and the entire germ was smaller and less developed. The walls of the developing alveolus were thinner and showed lower bone density than in controls.

At 15 days of age, the first molars were in the mucosa penetration stage, in which the crown is only covered by the oral mucosa and the bone overlying the crown has resorbed completely so that the tooth can open its eruption pathway. The upper portion of the cortical plates of the alveolus was separated from the enamel organ remnant by primitive connective tissue. Periodontal ligament fibers were inserted in the cortical bone plate and in the developing tooth root. The first molars of animals exposed to CrVI, however, had erupted less and were less developed,

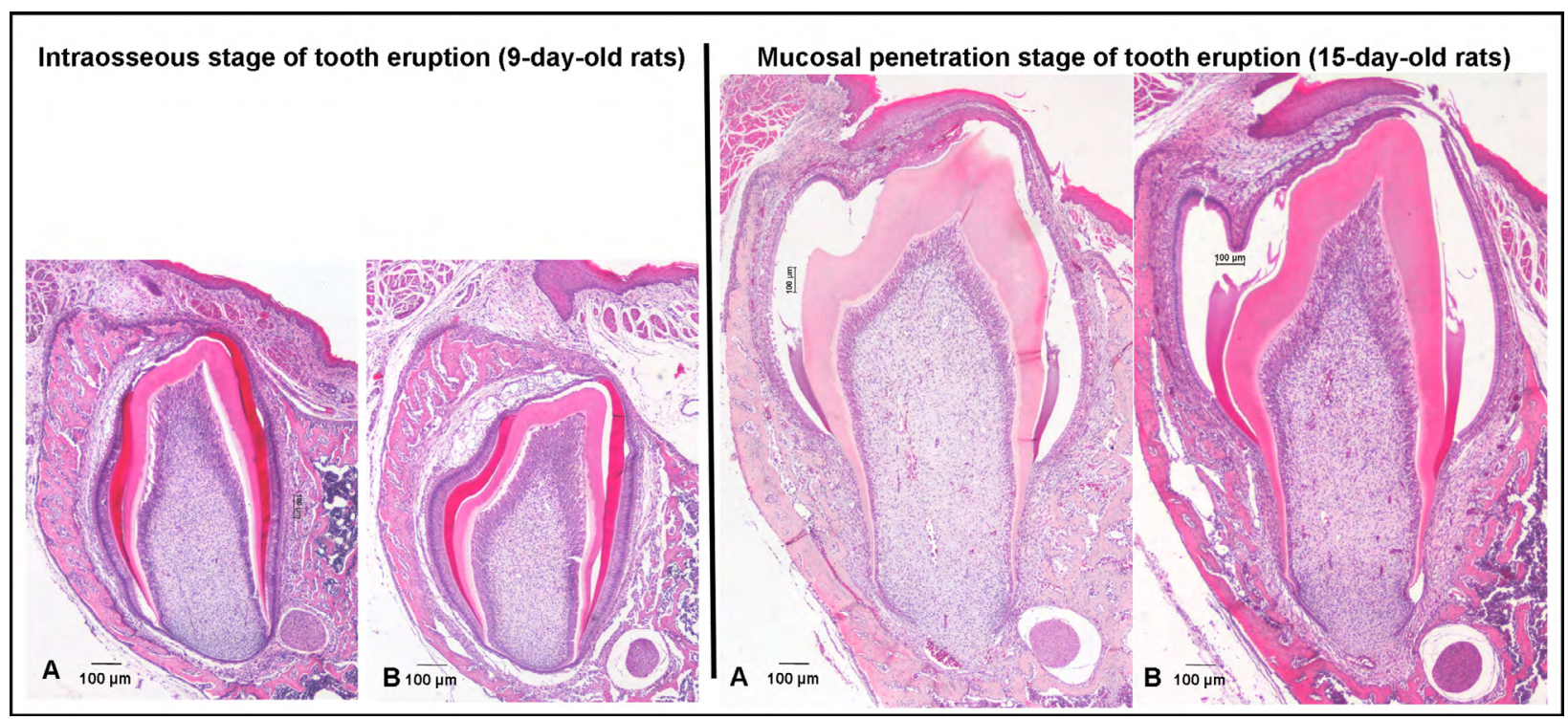

Fig.1: Buccolingual sections at the level of the mesial root of the first lower molar of 9-and 15-day-old animals. A. Control animals. B. CrVI-exposed animals. Nine-day-old exposed animals showed a less erupted tooth germ covered with thicker bone and less developed crown tissues than controls. Molars of 15-day-old exposed animals were less erupted with less developed crown tissues and less developed roots than control molars. 
and the periodontal space around both the developing crown and root was smaller than in controls. The crown and roots were smaller, the Hertwig's sheath was longer, and the bone volume of the developing bony crypt was lower.

Nine-day-old experimental animals showed fewer erosion surfaces on the buccal and lingual sides of the developing alveolus than their age-matched controls. Conversely, 15-day-old experimental animals showed more erosion surfaces at the aforementioned sites than their matched controls (Fig. 2). In addition, the

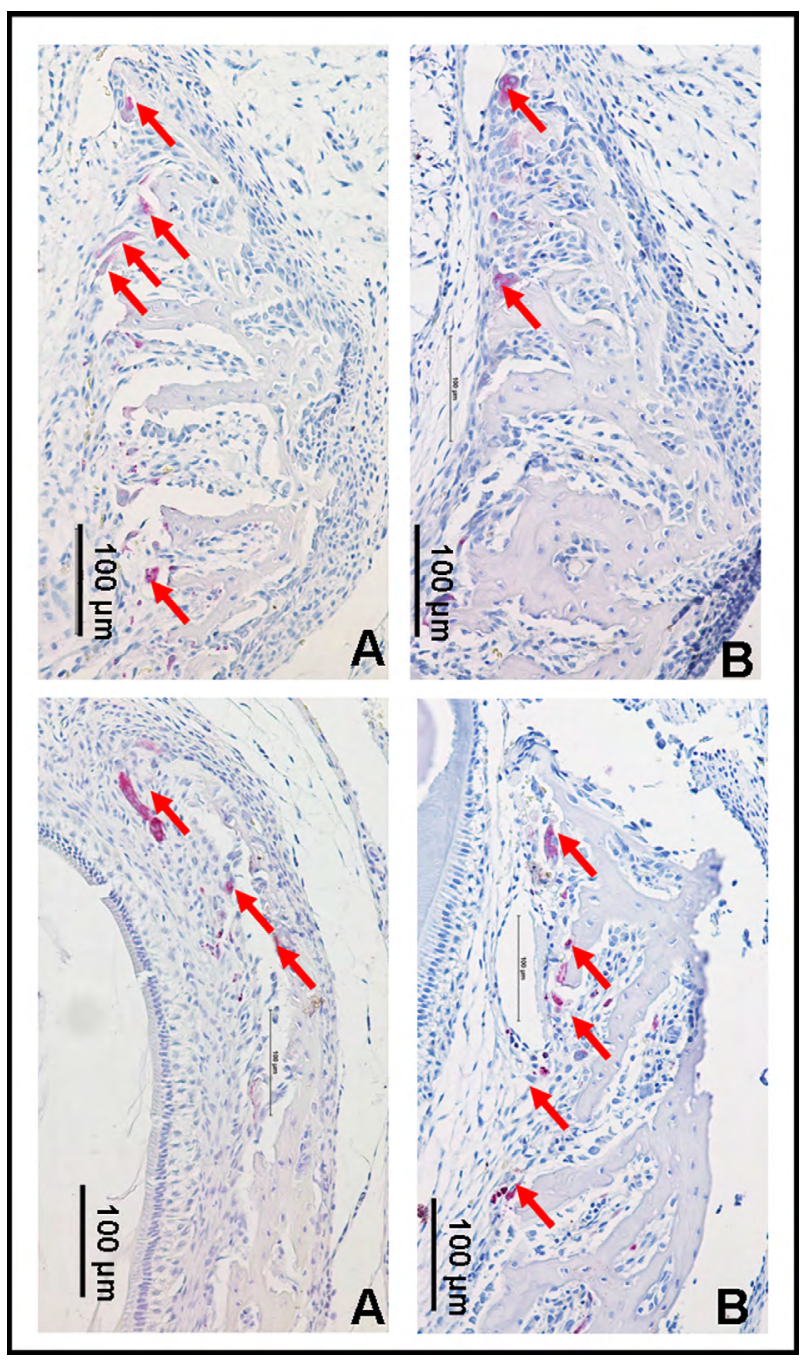

Fig 2: Buccolingual sections at the level of the mesial root of the first lower molar of 9-and 15-day-old rats. TRAP detection, hematoxylin counterstained. The upper and lower images correspond to 9- and 15-day-old animals, respectively. A. Control rat. B. CrVI-exposed rat. Nine-day-old CrVI animals showed fewer TRAP+ resorption surfaces (red arrows) than their age-matched controls. Conversely, 15-day-old CrVI animals showed more TRAP+ resorption surfaces (red arrows) than their matched controls. In addition, bone trabeculae of both 9- and 15-day-old CrVI animals were thicker and larger.
Table 1: Percentage of bone resorption surfaces in 9- and 15-day-old animals

Control
Group

Buccal side

Intraosseous stage/

age 9 days

$50.81 \pm 2.68 \quad 36.98 \pm 3.21^{*}$

Mucosal penetration stage /age 15 days

$39.05 \pm 3.01 \quad 60.91 \pm 9.7^{*}$

Lingual side

Intraosseous stage/

age 9 days

$69.66 \pm 5.81 \quad 29.58 \pm 5.81^{*}$

Mucosal penetration stage/age 15 days

$39.58 \pm 6.32 \quad 62.95 \pm 8.34$

Results are expressed as mean and standard deviation, ${ }^{*} p<0.05$.

\section{Table 2: Percentage of bone formation surfaces in 9- and 15-day-old animals.

$\begin{array}{cc}\text { Control } & \begin{array}{c}\text { Experimental } \\ \text { Group }\end{array} \\ \end{array}$ \\ Buccal side

\begin{tabular}{|l|l|l|}
$\begin{array}{l}\text { Intraosseous stage/ } \\
\text { age } 9 \text { days }\end{array}$ & $65.55 \pm 2.91$ & $29.07 \pm 2.31^{*}$ \\
$\begin{array}{l}\text { Mucosal penetration/ } \\
\text { age } 15 \text { days }\end{array}$ & $51.34 \pm 3.91$ & $43.07 \pm 11.22$ \\
\hline $\begin{array}{l}\text { Lingual side } \\
\begin{array}{c}\text { Intraosseous stage/ } \\
\text { age } 9 \text { days }\end{array}\end{array}$ & $60.97 \pm 2.91$ & $49.08 \pm 5.88^{*}$ \\
\hline $\begin{array}{c}\text { Mucosal penetration/ } \\
\text { age } 15 \text { days }\end{array}$ & $30.71 \pm 2.89$ & $45.64 \pm 8.52$ \\
\hline Results are expressed as mean and standard deviation, ${ }^{*} p<0.05$
\end{tabular}

trabeculae of the walls of the developing alveolus of experimental animals were thicker and larger than those of controls at both stages of tooth eruption studied.

The histomorphometric study showed that the percentage of TRAP + surfaces at the study sites was significantly lower in 9-day-old experimental animals and significantly higher in 15-day-old animals than in the corresponding sites in their agematched controls (Table 1).

The buccal and the lingual sides of the developing alveolus of 9- and 15-day-old CrVI-exposed animals showed fewer osteoblast-covered bone surfaces than controls. The histomorphometric study showed that the percentage of ALP+ surfaces was lower in controls than in the corresponding sites of agematched experimental rats. The differences observed between groups at the intraosseous stage of tooth eruption were statistically significant (Table 2). 


\section{DISCUSSION}

To our knowledge, this is the first experimental study to analyze the effects of CrVI on tooth eruption. Our results showed that exposing suckling rats to CrVI delays resorption of the bone overlying the crown and bone formation on the lateral walls of the developing alveolus, delaying tooth eruption.

Bone resorption must take place for the tooth to move through the eruption pathway in all three spatial planes. Marks and $\mathrm{Cahill}^{28}$ reported that the dental follicle plays an essential role in regulating this process. It has been shown that the dental follicle produces chemotactic molecules, such as MCP-1 (Monocyte chemotactic protein-1) and CSF-1 (Colony stimulating factor-1), responsible for recruiting mononuclear cells that fuse to form osteoclasts, which are necessary for the alveolar bone to resorb ${ }^{29}$. According to reports in the literature, osteoclastogenesis in the developing alveolus of the first molar of rats increases towards day three after birth and then decreases towards $10-$ 16 age period ${ }^{30,31}$.

Our results in the control group agree with these data. In the CrVI group, we found a significantly lower percentage of TRAP + bone resorption surfaces in 9-day-old rats and a higher percentage of bone resorption surfaces in 15-day-old rats. This indicates alteration of the sequence of bone resorption in the walls of the developing alveolus that is necessary for the tooth to move through the eruption pathway. Exposure to CrVI is likely to affect the regulating function of the dental follicle, altering monocyte recruitment and fusion, consequently altering osteoclastogenesis and resorption of the developing alveolus, and causing a delay in the eruption.

Our observations are in agreement with studies reported in the literature. CrVI affects osteoclastogenesis and osteoclast function in vivo in rats ${ }^{32}$ and in humans ${ }^{33}$, since chromium interferes with monocyte differentiation into osteoclasts and inhibits the $\mathrm{Ca}^{2+}$ receptors in the osteoclast cell membrane. The binding site of the receptor is highly sensitive to divalent and trivalent cations, and because CrVI reduces to trivalent chromium, the latter could bind to the receptor, increasing the cytosolic concentration of calcium and decreasing bone resorption. In an in vivo study, Sankaramanivel et al. $^{20}$ showed a significant decrease in TRAP activity in the skull of exposed rats, which undergoes the same ossification mechanism as the jaws.

In addition, we found a lower percentage of ALP+ formation surfaces on the lateral walls of the developing alveolus of the first molar of CrVIexposed animals as compared to controls at both experimental times. The lower degree of bone formation in the walls of the tooth alveolus observed in our study are in agreement with the effects of CrVI exposure on osteoblasts described by other authors. Reports on in vitro cytotoxic effects of CrVI on mature osteoblasts include alterations in their synthesis function, cell morphology, and capacity to differentiate into osteocytes and bone lining cells ${ }^{34-36}$ as well as inhibition of bone mineralization ${ }^{37}$.

An interesting finding of the present study is that CrVI-exposed animals exhibited thicker and larger bone trabeculae than their matched controls at both experimental times. There are no reports in the literature to date on intoxication with CrVI or other heavy metals showing this very particular alveolar histoarchitecture, which may occur as a consequence of an alteration of the bone remodeling process with the ensuing delay in alveolar bone resorption during tooth eruption.

Although the dose of $12.5 \mathrm{mg} / \mathrm{kg}$ of body weight used in our study is lower than the median lethal CrVI dose (LD50) for rats, it is higher than the maximum allowed dose $(0.1 \mathrm{mg} / \mathrm{kg})$ for humans ${ }^{38}$. Environmental levels of CrVI in some large cities around the world are higher than the dose used here ${ }^{1-3}$. In fact, the daily dose of CrVI administered to the experimental animals in this study was similar to the dose that growing children are exposed to through drinking formula prepared with contaminated water. By delaying tooth eruption, exposure to $\mathrm{CrVI}$ could cause impaired occlusion and facial growth and development in exposed children. All dentists should therefore be well informed about these CrVI exposure-related disorders for early detection and prompt referral to the corresponding specialist. In addition, having information about the environment in which their patients have grown up helps dentists to diagnose these alterations accurately. 


\section{ACKNOWLEDGMENTS}

The authors thank Ht. Ivana Sánchez Rojas and Mariela Lacave for their technical assistance.

\section{FUNDING}

This study was supported by a grant from University of Buenos Aires, UBACyT program. Number 2014-2017 20020130100270.

\section{CORRESPONDENCE}

Dr. Luciana Marina Sánchez

Cátedra de Histología y Embriología, Facultad de Odontología, Universidad de Buenos Aires

Marcelo T. De Alvear $21421^{\circ}$ “A”. CP: 1122AAH.

Buenos Aires, Argentina.

luciana.sanchez@odontologia.uba.ar

\section{References}

1. Tziritis E, Kelepertis E, Korres G, Perivolaris D, Repani S. Hexavalent Chromium Contamination in Groundwaters of Thiva Basin, Central Greece. Bull Environ Contam Toxicol 2012, 89: 1073-1077.

2. Banu S, Stanley J, Taylor R, Sivakumar KK et al. Sexually Dimorphic Impact of Chromium Accumulation on Human Placental Oxidative Stress and Apoptosis. Toxicol Sci 2018;161: 375-387.

3. Stanislawska M, Janasik B, Kuras R, Malachowska B, Halatek T, Wasowicz W. Assessment of occupational exposure to stainless steel welding fumes - A human biomonitoring study. Toxicol Lett 2020;329:47-55.

4. Yang X, Duan J, Wang L, Li W, Guan J, Beecham S et al. Heavy metal pollution and health risk assessment in the Wei River in China. Environ Monit Assess. 2015,187:111.

5. Sun H, Brocato J, Costa M. Oral Chromium Exposure and Toxicity. Curr Environ Health Rep. 2015,2:295-303.

6. Kirman CR, Suh M, Proctor DM, Hays SM. Improved physiologically based pharmacokinetic model for oral exposures to chromium in mice, rats, and humans to address temporal variation and sensitive populations. Toxicol Sci 2017 15;325:9-17.

7. Izhar S, Goel A, Chakraborty A, Gupta T. Annual trends in occurrence of submicron particles in ambient air and health risk posed by particle bound metals. Chemosphere 2016;146:582-590.

8. Casey CE, Hambidge KM. Chromium in human milk from American mothers. Br J Nutr 1984, 52: 73-77.

9. Hernandez F, Bemrah N. Séby F, Noel L, Guérin T. Cr(VI) and $\mathrm{Cr}(\mathrm{III})$ in milk, dairy and cereal products and dietary exposure assessment. Food Addit Contam Part B Surveill 2019;12:209-215.

10. Kerger BD, Paustenbach DJ, Corbett GE, Finley BL. Absorption and elimination of trivalent and hexavalent chromium in humans following ingestion of a bolus dose in drinking water. Toxicol Appl Pharmacol. 1996;141:145-158.

11. Scientific Committee Health and Environmental Risks (SCHER). "Chromium VI in toys", 2015. https://ec.europa. $\mathrm{eu} /$ health/sites/health/files/scientific committees/ environmental_risks/docs/scher_o_167.pdf

12. Andreasen JO. Normal and disturbed tooth eruption in humans. In: Andreasen Jo, Petersen JK, Laskin DM, eds. Textbook and color atlas of tooth impactions. Diagnosis, treatment and prevention. Copenhagen: Munkksgaard, 1997; 19-47.

13. Wang XP. Tooth eruption without roots. J Dent Res. 2013, 92:212-214

14. Marks SC Jr, Schroeder HE. Tooth eruption: theories and facts. Anat Rec. 1996, 245:374-393.
15. Merzel J, Salmon CR. Growth and the modeling/remodeling of the alveolar bone of the rat incisor. Anat Rec (Hoboken). 2008, 291:827-834.

16. Wise GE, King GJ. Mechanisms of tooth eruption and orthodontic tooth movement. J Dent Res 2008, 87:414-434.

17. Henriksen K, Neutzky-Wulff AV, Bonewald LF, Karsdal MA. Local communication on and within bone controls bone remodeling. Bone 2009, 44: 1026-1033.

18. De Lucca RC, Dutrey PL, Villarino ME, Ubios AM. Effect of different doses of hexavalent chromium on mandibular growth and tooth eruption in juvenile Wistar rats. Exp Toxicol Pathol 2009, 61:347-352.

19. Sánchez LM, Lewicki M, De Lucca RC, Ubios AM. Impairment of bony crypt development associated with hexavalent chromium exposure during tooth eruption. Acta Odontol Latinoam 2015, 28: 203-209.

20. Sankaramanivel S, Jeyapriya R, Hemalatha D, Djody S, Arunakaran J, Srinivasan N. Effect of chromium on vertebrae, femur and calvaria of adult male rats. Hum Exp Toxicol 2006, 25: 311-318.

21. Howie DW, Rogers SD, Mc Gee MA, Haynes DR. Biologic effects of cobalt chrome in cell and animal models. Clin Orthop Relat Res 1996, 329 Suppl: S217-32.

22. Bailey MM, Boohaker JG, Sawyer RD, Behling JE et al. Exposure of pregnant mice to chromium picolinate results in skeletal defects in their offspring. Birth Defects Res B Dev Toxicol 2006, 77: 244-249.

23. Soudani N, Ben Amara I, Troudi A, Bouaziz H, Boudawara T, Zeghal N. Oxidative stress induced by chromium (VI) in bone of suckling rats. Toxicol Ind Health. 2011, 27:724734.

24. Blacksmith Institute (2007) Polluted Places- India. Final report January 2005- December 2007. Project implemented by Blacksmith Institute. Supported under Poverty and Environment Program (PEP), Asian Development Bank.

25. Weibel E, Elias H. Quantitative methods in morphology. In: Weibel ER, Elias H (eds). Introduction to stereology and morphology. 1967, Springer Verlag, Berlin, 3-19.

26. Parfitt AM. Bone histomorphometry: standardization of nomenclature, symbols and units (summary of proposed system). Bone 1987, 9:67-69.

27. Dempster DW, Compston JE, Drezner MK, Glorieux FH et al. Standardized Nomenclature, Symbols, and Units for Bone Histomorphometry: A 2012 Update of the Report of the ASBMR Histomorphometry Nomenclature Committee. J Bone Miner Res 2013, 28: 2-17.

28. Marks SC Jr, Cahill DR. Regional control by the dental follicle of alterations in alveolar bone metabolism during tooth eruption. J Oral Pathol. 1987, 16: 164-169. 
29. Liu D, Wise GE. A DNA microarray analysis of chemokine and receptor genes in the rat dental follicle-rol of secreted frizzled- related protein- 1 in osteoclastogenesis. Bone 2007, 41: 266-272.

30. Wise GE. Cellular and molecular basis of tooth eruption. Orthod Craniofac Res 2009, 12: 67-73.

31. Wise GE, Fan W. Changes in the tartrate-resistant acid phosphatase cell population in dental follicles and bony crypts of rat molars during tooth eruption. J Dent Res. 1989,68: 150-156.

32. Nichols KG, Puleo DA. Effect of metal ions on the formation and function of osteoclastic cells in vitro. J Biomed Mater Res 1997, 35: 265-271.

33. Neale S, Haynes D, Howie D, Murray D, Athanasou N. The effect of particle phagocytosis and metallic wear particles on osteoclast formation and bone resorption In Vitro. J Arthroplasty 2000, 15: 654-662.

34. Lohmann CH, Schwartz Z, Köster G, Jahn U et al. Phagocytosis of wear debris by osteoblasts affects differentiation and local factor production in a manner dependent on particle composition. Biomaterials 2000, 21:551-561.

35. Anissian L, Stark A, Dahistrand H, Granberg B, Good V, Bucht E. Cobalt ions influence proliferation and function of human osteoblast-like cells. Acta Orthop Scand 2002, 73: 369-374.

36. Monteiro C, Santos C, Bastos V, Oliveira H. Cr(VI)-induced genotoxicity and cell cycle arrest in human osteoblast cell line MG-63. J Appl Toxicol 2019; 39:1057-1065.

37. Andrews RE, Shah KM, Wilinson JM, Gartland A. Effects of cobalt and chromium ions at clinically equivalent concentrations after metal-on-metal hip replacement on human osteoblast and osteoclasts: implications for skeletal health. Bone 2011, 49: 717- 723 .

38. Toxicological profile for chromium. U.S. department of health and human services, Public Health Service Agency for Toxic Substances and Disease Registry, 2012. URL: https://www.atsdr.cdc.gov/toxprofiles/tp7.pdf 